\title{
Distribution and dispersion of the predatory intertidal gastropod Morula marginalba
}

\author{
M. J. Moran* \\ School of Biological Sciences, The University of Sydney, NSW Australia
}

\begin{abstract}
In New South Wales, the muricid gastropod Morula marginalba occurs intertidally on most rocky shores in lower estuaries and on the open coast. M. marginalba is absent from most wavebattered headlands and shores made up of massed large boulders. Experiments showed that physical dislodgement by waves was a sufficient explanation for absence of the whelks from areas of strong wave action. The xanthid crab Ozius truncatus is abundant on boulder shores and, in the laboratory, preyed on $M$. marginalba by breaking its shell. The crabs ate many more small than large snails. There is a size-related incidence of chipped shells in populations of $M$. marginalba adjacent to the boulder habitat, suggesting that the effects of predation by crabs on the snails ranges from slight and sizedependent mortality through to total exclusion. At times the snails form aggregations. Unlike some other species of muricid gastropods, $M$. marginalba did not aggregate to breed, feed or shelter from heavy waves. Clumping behaviour was positively related to the density of non-feeding snails. Whelks fed most when periods of submersion were longest, either due to spring tides or to big waves washing the shore. Since aggregations invariably occurred in pools or crevices, snails were probably sheltering from the effects of long periods of emersion and aggregations were seen when there were enough sheltering snails to form clusters. The snails changed their habitat with increasing body size, from moist, low-shore areas with very small prey, through to a higher intertidal habitat with large prey. Preferred barnacle prey were frequently abundant higher on the shore than the snails were naturally found. Snails caged at these higher levels were able to survive and feed, though at a reduced rate compared with those lower on the shore. These findings support a model of dispersion in which snails tend to remain at the lowest shore level at which suitable prey are sufficiently available; availability being a function of feeding rate and therefore shore height as well as abundance of prey.
\end{abstract}

\section{INTRODUCTION}

The marked gradients in both duration of submersion and exposure to wave action, together with the relative ease of observing the animals and plants, have long attracted students of the distribution of organisms to the rocky intertidal zone (e.g. Lewis 1964, Stephenson \& Stephenson 1949). Early views that the distributions of all intertidal organisms are determined directly by tolerance of the organisms to physical stress (e.g. Colman 1933, Evans 1947) have been challenged. The importance of biological factors such as predation (Connell 1961a), competition (Connell 1961b) and availability of food (Underwood 1979) began to be recognized. Physical variables such as height on the

Present address: Western Australian Marine Research Laboratories, P. O. Box 20, North Beach, Western Australia 6020 shore and location in a wave-exposure gradient have now been studied in the context of their effects on the intensity and outcome of biological interactions in the intertidal community (e.g. Dayton 1971, Menge 1976).

The potential complexity of such systems has been shown by the finding that the effectiveness of a predator can vary in different parts of its range (Menge, 1978 a b) and by investigations of the effects of various densities, rather than simple presence or absence of competing species (Underwood et al. 1983). The latter authors, as well as Dayton (1971), highlight the local patchiness of some rocky intertidal communities and indicate that future studies must consider the variations in abundance of organisms from place to place within their total distributional range. The studies of Menge $(1976,1978 a$, b) on the predatory gastropod Thais lapillus and its prey show that when a predator is a key species in the community, a knowledge of factors which influence the dispersion and activity of the pre- 
dator is vital to the understanding of community interactions.

Muricid gastropods are important predators in many intertidal communities and factors affecting distribution have been investigated for a number of species. The upper limits to the vertical distribution of some Thais species have been suggested to be determined by desiccation or the time available to find and consume prey in a single period of submersion. Other studies of vertical distribution of Thais species have dealt with shore-level size gradients (Bertness 1977. Butler 1979) or the relative vertical distributions of different age groups (Feare 1970a, Coombs 1973).

Aggregation by muricid gastropods has been observed in the species Thais lapillus (Feare 1970b) and $T$. lamellosa (Spight 1974) in relation to breeding activity. $T$. lapillus also aggregates when feeding (Connell 1961a); and Feare (1970b) suggested that this is an adaptation to resist dislodgement by heavy waves. Occupation of crevices has also been reported for a number of muricid species. Connell (1961a) noted that $T$. lapillus ceased feeding and sheltered in crevices during gales and cold weather. Menge (1978a) described the restriction of $T$. lapillus to crevices on all shores in winter and on shores exposed to heavy waves at all times of year. Menge (1974) suggested Acanthina punctulata shelter in crevices to avoid dislodgement by waves. $T$. lamellosa, $T$. emarginata, $T$. canaliculata (Dayton 1971, Connell 1970) and T. orbita (Phillips 1969, Black 1978, Butler 1979) are also frequently found in crevices.

The horizontal distribution of the thick-shelled form of Thais lapillus has been shown experimentally to be limited by strong wave action, and that of the thinshelled form of the same species by predation by crabs (Kitching et al. 1966). Feare (1970a) suggested that vertical distribution of a vulnerable age-class of $T$. lapillus is a response to predation by crabs. Morgan (1972) reported changes in the dispersion of a population of $T$. lapillus coincident with the recolonization of the area by preferred barnacle prey. Dayton (1971) and Connell (1970) also suggested that the dispersion of Thais spp. is affected by the abundance of suitable prey at different shore levels.

On many rocky shores of the southern part of the Australian east coast, the major, and often apparently the only predator in the mid-tidal zone, is the muricid gastropod Morula marginalba Blainville. M. granulata Duclos, which is probably synonymous with $M$. marginalba, is a major component of the predatory gastropod fauna studied on coral atolls of the tropical Indo-Pacific region (Kohn and Leviten 1976, Taylor 1976, 1978). These authors found that, when not feeding, Morula were frequently sheltering in thick algal mat, pools or crevices.
In the Sydney area of New South Wales, Meyer and O'Gower (1963) found that Morula marginalba was almost completely absent from shores exposed to strong waves. O'Gower and Meyer (1971) found $M$. marginalba to be more abundant at the edges of pools than in the pools or on rock which dried at low tide. In the present paper, the distribution and dispersion of this whelk in the Sydney area are described with respect to shore level, position in a wave-exposure gradient, presence of predatory crabs and densities of the prey of Morula. Relations between aggregation of Morula and wave strength, duration of emersion and season are investigated.

Other aspects of the biology of Morula marginalba which have been studied are the reproductive cycle and embryonic development. Underwood (1974) reported that $M$. marginalba have ripe oocytes in spring and summer. Anderson (1965) described batches of capsules each containing several hundred fertilized eggs, which develop for 2 to $3 \mathrm{wk}$ on the shore before hatching as planktotrophic veligers.

\section{MATERIALS AND METHODS}

Morula marginalba. Underwood (1974) gave the geographic distribution of Morula marginalba as extending through the Indo-Pacific region from Japan to southern New South Wales. The present study in Central NSW is therefore a few hundred $\mathrm{km}$ from the southern limit of this species. In this area, M. marginalba occurs on rocky shores in the seaward parts of estuaries and on the open coast, though not in areas of the most extreme exposure to waves (Fig, 1). Sublittoral sightings of the snail are very rare and it is never seen on sand. The greatest densities are found in the mid-intertidal, or barnacle zone, with few occurrences in the low intertidal, or algal zone, or in the upper intertidal or littorinid zone (see diagrams in Underwood 1975, 1981). This agrees with the situation on the rocky shores of the Queensland mainland (Endean et al., 1956).

Like other muricid gastropods (Carriker 1955), Morula marginalba has the ability to bore holes in the calcareous shells of barnacles, serpulid polychaetes and molluscs. I have observed these snails feeding on almost every species of shelled animal with which it co-occurs. Species eaten in the Sydney area are listed by Fairweather and Underwood (1983), who investigated preferential predation by $M$. marginalba.

Study areas. Main experiments and observations were made on 2 rock-platforms at Tamarama near Sydney, NSW. The rock is sandstone, weathered into roughly horizontal platforms at several levels, with large, shallow pools which may be up to $10 \mathrm{~m}$ across 


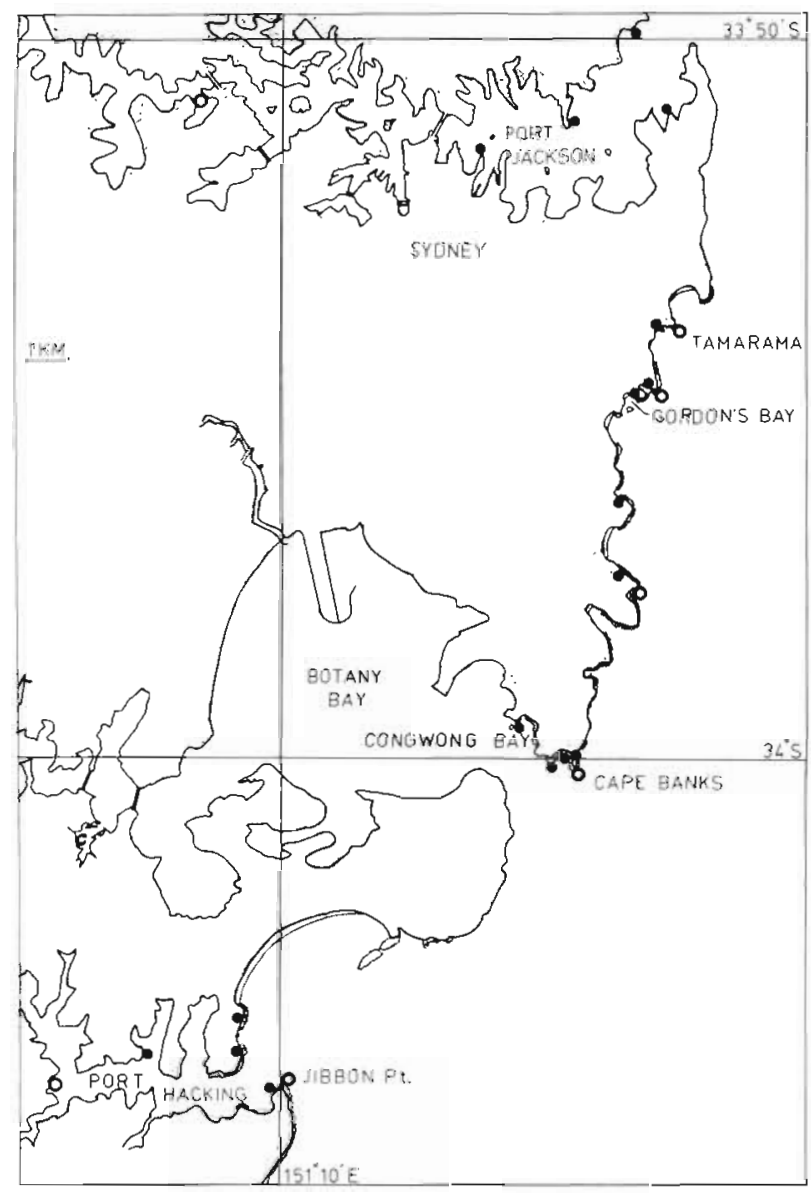

Fig. 1 Coastline of Sydney region, showing rocky shores examined for Morula marginalba. Closed circles: sites where snails were found; open circles: sites where snails were not found

but usually only 10 to $20 \mathrm{~cm}$ deep. Boulders appear to be formed both by undercutting the cliff at the back of the platforms at high tide level, and by undercutting the steps in the intertidal zone proper, but were absent from the most wave-exposed parts of the platforms. Of these 2 main platforms, the more northerly one (A) protrudes further into sea and its point receives the heaviest waves. Platform B is protected on its northern side by Platform $A$, and on its eastern side by a large, detached mass of rock (Fig. 2). The lower layer of Platform B slopes gently down at its northern and southern edges into the true algal zone, i.e. $100 \%$ cover of foliose algae. Most of the platform at this level is covered by mixed patches of the tubeworm Galeolaria caespitosa (Lamarck) and branching coralline algae, with slightly higher ridges of rock supporting herbivorous gastropods, mainly the limpet Cellana tramoserica (Sowerby) and temporary populations of the barnacle Tesseropora rosea (Krauss), mostly as juveniles. The alga Ulva lactuca (L.) is usually found growing epiphytically on G. caespitosa and Corallina sp. rather than directly on the rock. The eastern edge of this lower level is an abrupt drop into a deep channel. On the western side it is bounded by the edge of the upper layer, forming a mini-cliff which bears mainly adult $T$. rosea. The southern, unprotected side of Platform $B$ is the most exposed to waves, but even these are much lighter than the waves striking the exposed end of Platform A.

Other studies were at Gordon's Bay, Clovelly, several kilometres south of Tamarama; the shore is of similar composition and orientation to the Tamarama A platform, but less exposed to strong waves. The more sheltered end of this shore has numerous large boulders.

Sampling. All sampling was done using $0.25 \mathrm{~m}^{2}$ quadrats divided into 100 regularly-spaced points by crossstrings. Percentage cover of attached species was estimated by counting the number of grid points overlying that species. Densities of snails were determined by collecting all snails in the quadrat and replacing them after counting. Because erosion of the spire of Morula marginalba shells occurs commonly, measurements were made of aperture-length as in Meyer and O'Gower (1963).

Experimental enclosures. Cages were used to enclose Morula marginalba with barnacles. These were $23 \times 23 \mathrm{~cm}$ basal area and $3 \mathrm{~cm}$ high, made of
Fig. 2. Shores A and B at Tamarama, showing locations of transects used for sampling

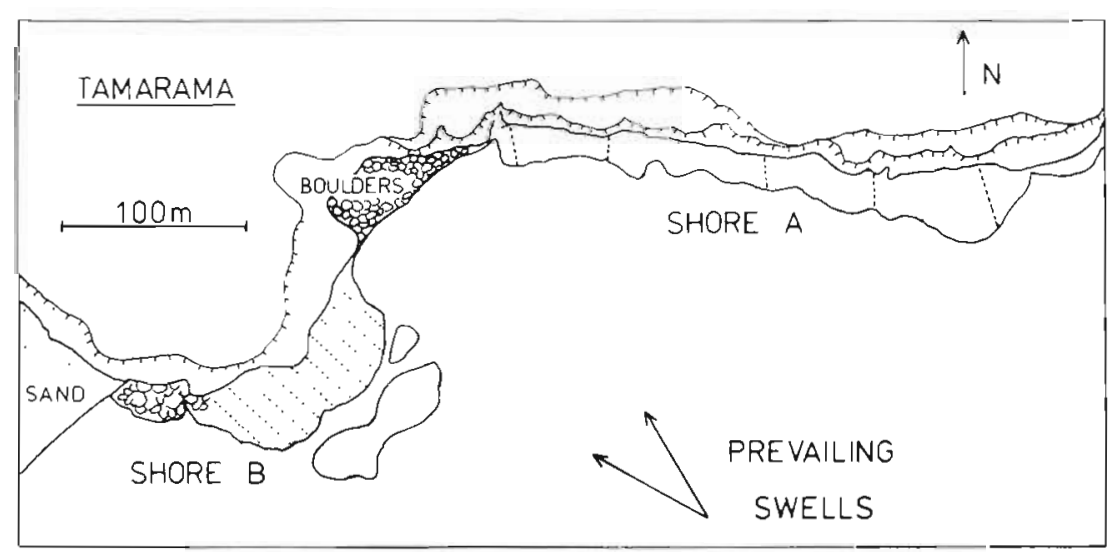


18 gauge stainless steel, 4 meshes to the inch, and fastened by stainless-steel screws to rawl-plugs in the rock. All macroscopic organisms other than the barnacles required in the caged area were removed with a chisel. The rock was then scrubbed with a stiff brush and left to be washed by the tide for several days before the snails were introduced to the cage.

Measurement of wave-shock. Maximal wave-shock was measured using the gauges described by Jones and Demetropoulos (1968); these were set for a single high tide period at a time. The strongest wave to strike the device during that period was recorded as $\mathrm{kg} \mathrm{cm}^{-2}$ of drogue. An average wave is difficult to define, but the strongest wave, measured parallel with the rock surface, is probably a more reliable variable when dislodgement of whelks is being considered.

\section{RESULTS}

Distribution and abundance of snails and prey along a wave-exposure gradient

Five transects, perpendicular to the low-water line and extending from the top of the barnacle zone to the top of the algal zone, were marked at approximately equal intervals along the shore A at Tamarama. Wave shock was measured at mid-tidal level on each transect during at least 3 high-tide periods. Morula marginalba, Thais orbita (Gmelin), and main species of prey were measured in contiguous quadrats along each transect (Fig. 3). Several species of herbivorous gastropods, which $M$. marginalba were not observed to eat on this shore, were present but not recorded. Oysters Saccostrea commercialis (Iredale \& Roughley), and the barnacle Chthamalus antennatus Darwin occurred on the shore but did not reach more than $1 \%$ cover in any quadrat sampled. The surf barnacle Catomerus polymerus (Darwin) was present on the most exposed transect, up to $24 \%$ cover, but was present at less than $1 \%$ on the other transects and was not observed being eaten by $M$. marginalba. The prey species most commonly attacked on this shore was the barnacle Tesseropora rosea, followed by the tubeworm Galeolaria caespitosa, the small barnacle Chamaesipho columna Spengler, and the barnacle Tetraclitella purpurascens (Wood).

There was very great variability in density from one quadrat to the next within any species' vertical range. This patchiness is typical of the sandstone shores of the central NSW coast (e.g. Underwood 1981). The pattern of decreasing abundance of Morula marginalba with increasing wave exposure is very clear (Fig. 3). The main species of prey were abundant on all 5 transects but $M$. marginalba was totally absent from the most exposed transects ( 4 and 5 ), represented by a single

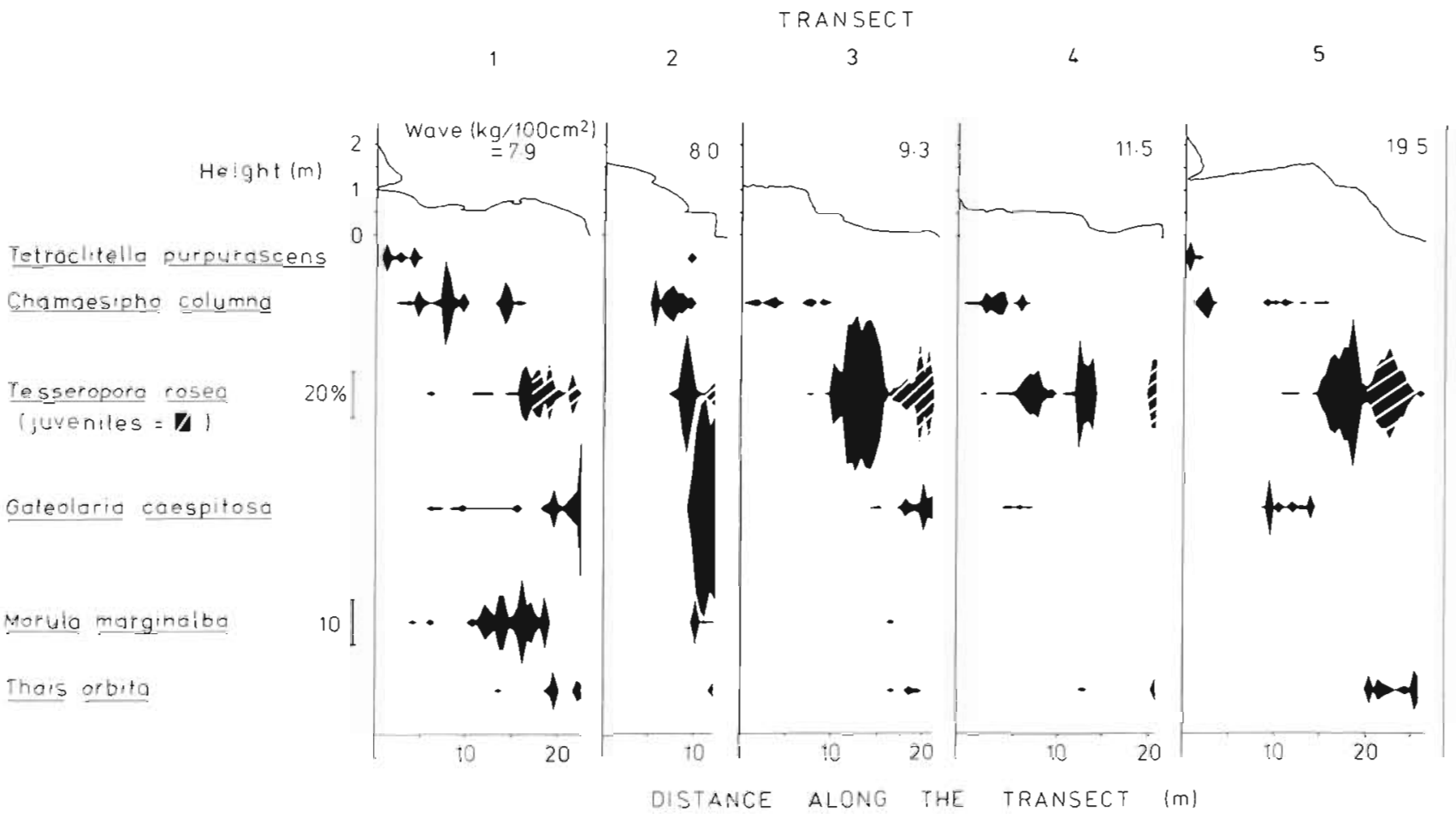

Fig. 3. Abundance of the whelks Morula marginalba and Thais orbita and their prey in contiguous $0.25 \mathrm{~m}^{2}$ quadrats along transects on Tamarama shore A. The 5 transects are arranged in increasing order of wave exposure: an index of wave-shock and the shore profile are shown above each transect 
individual in Transect 3 , then increasingly abundant on the most sheltered Transects 2 and 1. Thais orbita, which, - like Morula - preys heavily on the barnacle Tesseropora rosea in the mid-intertidal zone, showed no trend in abundance along the gradient of wave exposure. Even on the 2 most sheltered transects, where densities of $M$. marginalba were great, there was no correlation with densities of any single species of prey, nor of combinations of prey. The $M$. marginalba present on Transects 2 and 3 were situated close to the border between adult and newly-settled juvenile Tesseropora rosea, which had settled lower on the shore than most of the adults.

\section{Direct effects of waves in limiting the snail's distribution}

The simplest hypothesis for the absence of Morula marginalba from areas of exposure to strong waves, as revealed in the sampling described above, is that they cannot remain attached when struck by these waves. Thus, an experiment was designed to examine the survivorship of groups of snails at different places along the gradient of wave-exposure. Groups of 30 adult snails (13 to $17 \mathrm{~mm}$ aperture length) were collected and marked with coloured spots of marine paint to identify each group. One group was placed at each of 4 positions along the gradient of exposure to waves, at mid-shore level during low tide. Sea water was poured over the snails until they had all attached and could not be dislodged by a slight push with a finger. On the following day, all painted $M$. marginalba that could be found were collected. Searches were made for at least $4 \mathrm{~d}$ after release to try to ensure that all survivors were found. The whole process was replicated 3 times, on different days.

There was a highly significant effect of wave action on survival. Almost all Morula marginalba survived in sheltered places, but very few in exposed places, (Table 1; analysis of variance, arcsine transformation; $P<0.01$ ). These results cannot be explained by simple movements of snails to another part of the shore nor by

Table 1. Morula marginalba. Proportions of groups of 30 individuals which survived at least $1 \mathrm{~d}$ at each of 4 sites along a gradient of wave exposure. Means and (SE) of 3 replicates

\begin{tabular}{|crrrr|}
\hline Site & $\begin{array}{c}\text { Wave shock } \\
\left(\mathrm{kg} 100 \mathrm{~cm}^{-2}\right)\end{array}$ & \multicolumn{2}{c|}{$\begin{array}{c}\text { Proportion } \\
\text { surviving }\end{array}$} \\
\hline 1 & 7.9 & $(0.6)$ & 0.89 & $(0.03)$ \\
2 & 9.3 & $(0.6)$ & 0.68 & $(0.11)$ \\
3 & 11.5 & $(1.6)$ & 0.47 & $(0.04)$ \\
4 & 19.5 & $(4.8)$ & 0.18 & $(0.08)$ \\
\hline
\end{tabular}

whelks being more difficult to find at the exposed end of the shore. The brightly painted shells were very easily seen on these flat, open shores. Thus the direct effects of waves in dislodging the snails can explain the absence of the whelk from areas of great wave exposure.

Effects of wave exposure and duration of submersion on the snail's feeding rate

Although dislodgement by waves restricts Morula marginalba to areas where wave shock is not extreme, within areas where the snails can resist dislodgement, wave action may also be relevant by affecting the availability of prey. Similarly, the duration of submersion may affect the availability of prey to the snails over a range of shore levels at which prey are present and the snails are capable of feeding. An experiment was designed, therefore, to determine whether the number of barnacles eaten during a given period was affected by the duration of submersion and/or the relative exposure to waves. On the same shore as the experiment just described, groups of 5 adult $M$. marginalba (14 to $16 \mathrm{~mm}$ aperture length) were placed in cages with 20 adult barnacles Tesseropora rosea. The 2 ends and the middle of the exposure gradient were chosen as the levels of wave exposure and at each of these places, 3 replicate cages were attached at each of 3 heights on the shore. The levels chosen at the 3 sites along the platform were the highest, lowest and middle levels at which adult $T$. rosea could be found in sufficient densities to provide 20 per cage. The duration of submersion in the period 6 a.m. to $6 \mathrm{p}$. m. was noted for each set of replicate cages on each day the experiment was in progress. The ranges of the mean proportions of time spent underwater in the high, medium and low sets of cages were, respectively, 0.08 to 0.13 ; 0.31 to 0.44 ; and 0.63 to 0.83 . In all cases the most exposed sites had the longer submersions within these ranges.

The experiment ran for $8 \mathrm{~d}$, at the end of which, the number of surviving barnacles in each cage was recorded. Daily observations showed that all dead barnacles had been drilled through the shell and therefore were not likely to have died from other causes than being killed by Morula marginalba. Both the position in the wave-exposure gradient and the duration of submersion had significant effects on the number of barnacles eaten $(\mathrm{P}<0.05)$, but the interaction between these factors was not significant $(P>0.25)$ (analysis of variance of the means in Table 2).

In a situation where 5 Morula marginalba are caged with 20 barnacles, therefore, a longer period of submersion leads to faster consumption of barnacles; and 
Table 2. Numbers of barnacles Tesseropora rosea killed by 5 Morula marginalba in 8 d, at 3 shore levels at each of 3 sites along a gradient of wave exposure; means and (SE) of 3 replicates are given: wave shock is shown as the mean with (SE) of 7 measurements and submersion as the total hours submersed during daylight ( 6 a.m. to 6 p.m.) for $8 \mathrm{~d}$

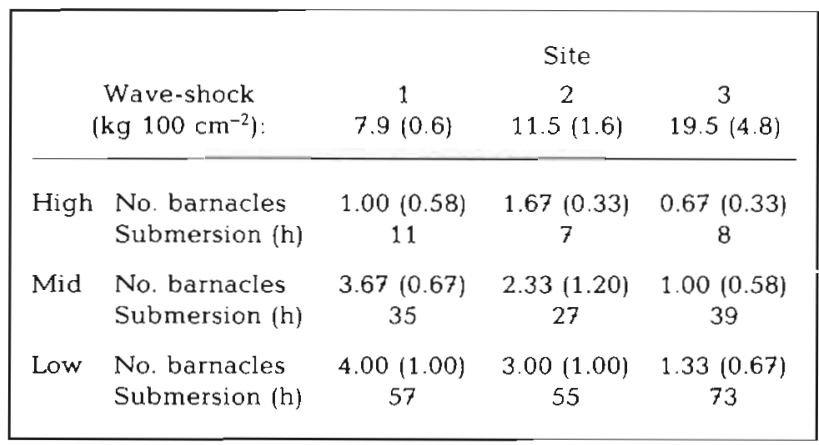

subjection to waves of increasing force reduces this consumption. No snails died in any cages during this experiment. Thus, although some protection from the environment was probably afforded by the cages, the snails were capable of surviving and feeding in cages for periods as long as $8 \mathrm{~d}$ at higher levels on the shore than they were actually found.

\section{Effect of density of prey and other attached organisms on dispersion of different snail sizes}

Tamarama shore B was sampled every 2 mo for 1 yr, May 1976 to July 1977, then less frequently for another $3 \mathrm{yr}$, as part of a study of the population dynamics of Morula marginalba (Moran 1980). Ten permanent transects, $10 \mathrm{~m}$ apart and approximately $30 \mathrm{~m}$ long, were marked on the shore, running parallel to each other from points above the barnacle zone to the lowest accessible points on the shore at low tide in normal weather. Seven points along each transect were chosen for each sampling date using random number tables. Quadrats $\left(0.25 \mathrm{~m}^{2}\right)$ were placed at each of the chosen points and the covers of attached organisms (species of Tesseropora, Galeolaria, Corallina and Ulva) were estimated on a scale of 0-10. All $M$. marginalba found in the quadrats were measured and divided into 4 size ranges, $<9 \mathrm{~mm}$ which corresponds to the first year of life, 9.5 to $12 \mathrm{~mm}$ corresponding to the second year, 12.5 to $15 \mathrm{~mm}$ which are adults and $15 \mathrm{~mm}$ as large adults (see details in Moran 1980). For the regular samples from May 1976 to July 1977, snail densities were subjected to multiple regression analysis. A number of quadrats on each transect fell above the highest point on the shore at which any snails were ever found. These were removed from the analysis as being outside the range of all snail sizes. This gave 312 quadrat samples for the regression. The independent variables used were the cover of the 4 main species of attached organisms, the transect number and the sine and cosine of the day of the year $\left(365 \mathrm{~d}=360^{\circ}\right)$. Since the southern part of shore $B$ receives heavier waves, and transect numbers run from north to south, transect number can be used as a rough index of exposure to waves. The sine and cosine of the date can together describe any sinusoidally fluctuating variable with a period of one year, regardless of phase.

The regression coefficients and their significance levels are shown in Table 3 . The density of the smallest size class was positively related to the cover of Galeolaria caespitosa and Corallina sp. and the density of the second smallest (9.5 to $12 \mathrm{~mm}$ ) Morula marginalba group was positively related to the cover of $G$. caespitosa. Densities of both these groups were negatively associated with exposure to waves and were significantly seasonal, peaking in the summer. Densities of 12.5 to $15 \mathrm{~mm}$ snails were positively associated with $G$. caespitosa and Tesseropora rosea,

Table 3. Morula marginalba. Multiple regressions of the densities of 4 size groups. Regression coefficients (b) and ' $\mathrm{t}$ ' values used to test the significance of partial regressions on different variables

\begin{tabular}{|c|c|c|c|c|c|c|c|c|}
\hline \multirow{3}{*}{ Variable } & \multicolumn{8}{|c|}{ Size } \\
\hline & \multicolumn{2}{|c|}{$<9 \mathrm{~mm}$} & \multicolumn{2}{|c|}{$9.5-12 \mathrm{~mm}$} & \multicolumn{2}{|c|}{$12.5-15 \mathrm{~mm}$} & \multicolumn{2}{|c|}{$>15 \mathrm{~mm}$} \\
\hline & $b$ & $\mathrm{t}$ & $b$ & $\mathrm{t}$ & $b$ & $\mathrm{t}$ & $b$ & $t$ \\
\hline Intercept & 1.39 & & 4.55 & & 3.10 & & 0.58 & \\
\hline Transect no. & -0.265 & $2.51^{\circ}$ & -0.497 & $4.78 \cdots$ & 0.086 & 0.73 & 0.108 & 1.50 \\
\hline Tesseropora & 0.006 & 0.02 & -0.200 & 0.78 & 0.902 & $3.11^{\cdots}$ & 1.396 & $7.84^{\cdots} \cdots$ \\
\hline Galeolaria & 0.371 & $2.98 \cdots$ & 0.604 & $4.93^{\cdots}$ & 0.529 & $3.81 \cdots$ & -0.017 & 0.20 \\
\hline Corallina & 0.197 & $2.02^{\circ}$ & 0.019 & 0.19 & -0.268 & $2.45^{\circ}$ & -0.109 & 1.62 \\
\hline Ulva & -0.195 & 1.41 & -0.234 & 1.71 & -0.253 & 1.62 & -0.094 & 0.99 \\
\hline Sin day of $y r$ & 0.285 & 0.59 & -0.118 & 0.25 & 0.034 & 0.06 & 0.146 & 0.44 \\
\hline Cos day of yr & 1.163 & $2.63 \cdots$ & 0.938 & $2.15^{\circ}$ & -0.415 & 0.83 & -0.032 & 0.11 \\
\hline
\end{tabular}


and the largest snails $(>15 \mathrm{~mm})$ were positively associated only with $T$. rosea. Viva lactuca had no significant effect on snail density at any size. It should be noted that less than $30 \%$ of the variance in density of all snail size groups was explained by the regression. This is consistent with the observation that densities of $M$. marginalba can vary greatly within a habitat and may be related to its aggregative tendency (see below).

\section{Role of crabs in limiting snail distribution}

On a number of shores in the Sydney region, Morula marginalba are abundant on sections consisting simply of the sandstone bedrock but absent from adjacent sections made up of massed boulders, even when the boulder areas have similar or greater cover of preferred prey such as Tesseropora rosea. Whilst sampling several such Morula-deficient shores at night, I have found 3 species of crabs that are large enough to hold a M. marginalba shell. These are Plagusia chabrus (Linnaeus), Leptograpsus variegatus (Fabricius) and Ozius truncatus (Milne-Edwards). Three large specimens of each species were collected and each crab was placed in an aquarium with 20 snails. Neither Plagusia chabrus nor Leptograpsus variegatus killed or chipped the shells of any snail. The 3 Ozius truncatus ate many of the snails given to them and chipped the shells of many more.

On the northern side of Gordon's Bay, Clovelly, a large population of Morula marginalba was found towards the western end of the platform. Around the boulders at the other end of the shore, the snails were absent and Ozius truncatus were seen foraging at night. A sample of $892 \mathrm{M}$. marginalba were collected from the part of the population closest to the boulder area; each snail was measured and examined for shell damage similar to that caused by $O$. truncatus in aquaria. Overall, $15 \%$ of the snails had chipped shells and there were significantly greater proportions of chipped shells in the 11 to 12 and 13 to $14 \mathrm{~mm}$ than in the larger or smaller, size classes $\left(\kappa^{2}=23.6, \mathrm{P}<0.05\right.$, 5 d. f.; see Fig. 4). In contrast to this population, thousands of $M$. marginalba from the Tamarama $B$ platform have been measured and very few had chipped shells.

To examine the vulnerability of Morula marginalba of different sizes to predation by Ozius truncatus, 40 . truncatus, carapace widths 50 to $59 \mathrm{~mm}$, were placed in separate aquaria in the laboratory. Each crab was given 55 snails, all with undamaged shells, 5 of each $1 \mathrm{~mm}$ size class from 8 to $18 \mathrm{~mm}$ inclusive. The aquaria were supplied with continuously flowing seawater and had close-fitting lids so that no snail could escape. At

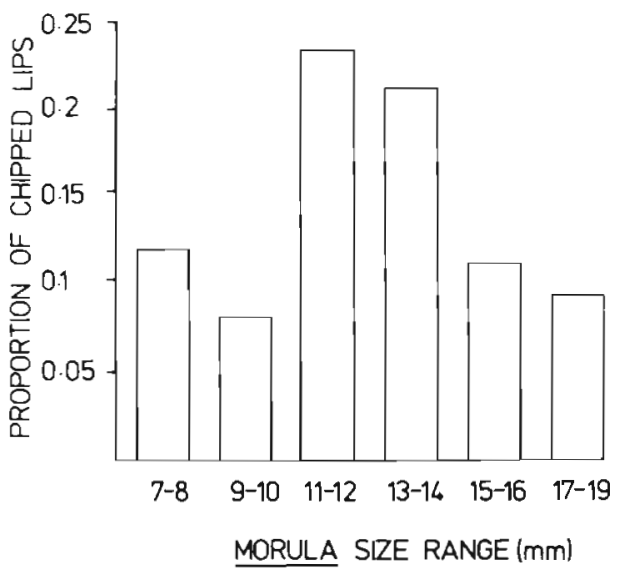

Fig. 4. Proportion of chipped shells by size class in a population of Morula marginalba adjacent to an area where the crabs Ozius truncatus were plentiful $(\mathrm{N}=892)$. Shell damage was similar to that caused by $O$. truncatus attacks in the laboratory

the end of a week all surviving snails were measured and the number killed in each size class recorded. As a control, many snails of all sizes were kept for many weeks in these aquaria without crabs; they showed no mortality.

Decreasing mortality with increasing size of snails was obvious (Fig. 5). There was some mortality in each

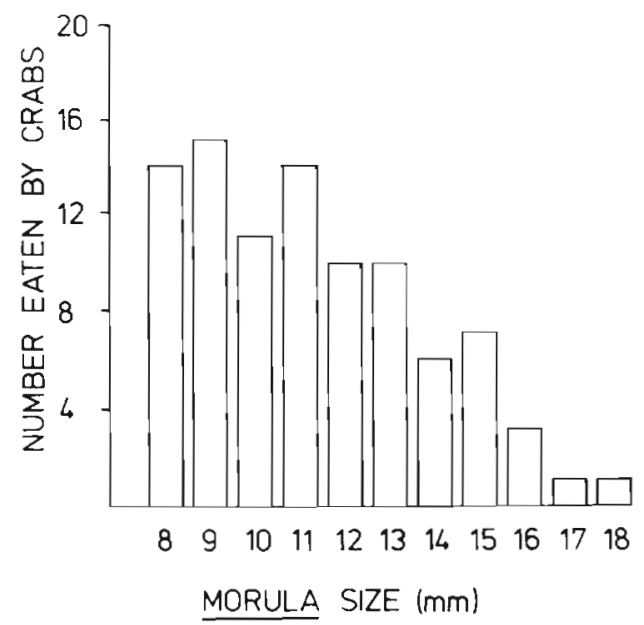

Fig. 5. Number of Morula marginalba out of 20 in each size class killed by crabs Ozius truncatus in the laboratory

size class, but only one (out of 20) of the $17 \mathrm{~mm}$ and $18 \mathrm{~min}$ snails were killed, compared with the 14 and 15 killed in the $8 \mathrm{~mm}$ and $9 \mathrm{~mm}$ size classes. As evidence that other large snails can survive such attacks, 11 of 39 survivors of the 2 largest size classes had chipped shells compared with none of the 11 survivors of the 2 smallest size classes. Thus all sizes of Morula marginalba in the range 8 to $18 \mathrm{~mm}$ are vulnerable to 
predation by Ozius truncatus, though perhaps large snails less so than small ones.

\section{Aggregating and sheltering behaviour}

To investigate the relation between aggregating behaviour of Morula marginalba and wave action, duration of submersion, feeding, reproductive activity and season, the following sampling programme was conducted. An area of shore was chosen on the Tamarama B platform in which 36 quadrats $\left(0.25 \mathrm{~m}^{2}\right)$ were arranged to form a large square, the corners of which were marked by nails in the rock. For $1 \mathrm{yr}$, March 1976-March 1977, at intervals of 3 or $5 \mathrm{wk}$, all snails in the area were examined and counted as being in the following categories: feeding (i.e. sitting on top of a new drill hole, complete or not, in a prey individual, or holding a detached small gastropod within the shell aperture); aggregating (being a member of a group of at least 3 whelks, the shells of which were touching); neither feeding nor aggregating; mating (the mating position of whelks is characteristic, with the male attached to the right side of the female's shell, close to the lip).

The force of the strongest wave was measured during the high tide period prior to sampling Morula marginalba. Duration of submersion, assuming calm seas, during the $24 \mathrm{~h}$ prior to sampling, was calculated from tide tables for each time of sampling. Since the study area is in the upper half of the intertidal zone, submersion is long at spring tides and short at neap tides. Multiple regression analysis was used to evaluate the response of the snail population to the various environmental factors.

There was a strong, inverse relation between the proportion of the population feeding and that aggregating ( $r=-0.99, n=5$, March-July 1976); aggregating snails were never feeding. The analysis was therefore divided into 2 sections. The first examined effects on feeding activity, the second dealt with the proportion of non-feeding snails which were aggregating. Factors tested for their effect on feeding were: force per unit area of the strongest wave during the previous high tide; duration of submersion in the previous $24 \mathrm{~h}$; proportion of the population mating; seasonality, as the sine and cosine of the day of the year $\left(365 \mathrm{~d}=360^{\circ}\right)$. Of these, neither proportion mating nor time of year had any effect, whether tested separately or together, indicating that the snails do not cease feeding during their breeding season. This finding was corroborated by frequent observations of females continuing to feed whilst copulating. Both wave-strength and submersion duration had positive effects on the proportion of the population which was feeding (Fig. 6; Table 4).

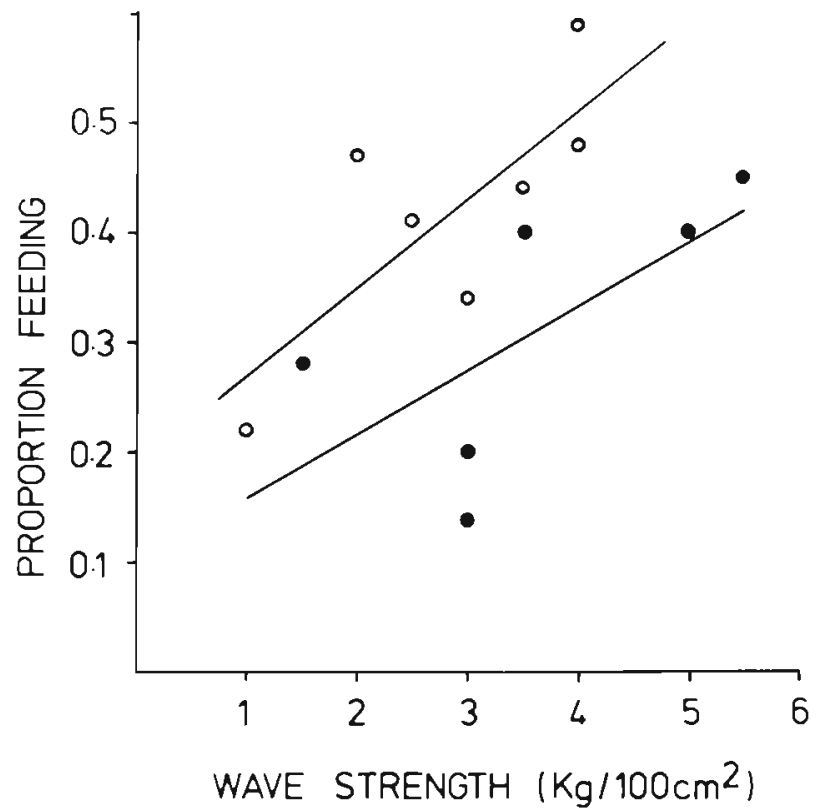

Fig. 6. Morula marginalba. Effects of wave strength and calculated tidal submersion in the previous $24 \mathrm{~h}$ on the proportion of a population feeding at low tide - submersion less than mean value of $4.5 \mathrm{~h}$., [Propn. feeding $(P)=0.11+0.06$ $\times$ Wave-strength $(W), r=0.67] ; O$ submersion longer than $4.5 \mathrm{~h}[\mathrm{P}=0.19+0.08 \times \mathrm{W}, \mathrm{r}=0.77]$

Table 4. Morula marginalba. Regression analyses of the effects of environmental variables on the proportion of snails feeding and aggregating

\begin{tabular}{|c|c|c|c|c|}
\hline $\begin{array}{l}\text { Dependent } \\
\text { variable }\end{array}$ & $\begin{array}{l}\text { Independent } \\
\text { variable }\end{array}$ & $\begin{array}{l}\text { Regression } \\
\text { coefficient }\end{array}$ & t-value & $P$ \\
\hline \multirow[t]{3}{*}{ Proportion feeding } & Intercept: & 0.15 & 1.216 & $>0.20$ \\
\hline & Period of submersion $(\mathrm{h})$ : & 0.0398 & 2.961 & $<0.01$ \\
\hline & Strength of wave $\left(\mathrm{kg} 100 \mathrm{~cm}^{-2}\right)$ : & 0.0454 & 4.903 & $<0.01$ \\
\hline \multicolumn{5}{|c|}{ Multiple correlation coeff.: $\mathrm{r}=0.62, \mathrm{r}^{2}=0.39,48$ d.f. } \\
\hline \multirow[t]{2}{*}{ Proportion aggregating } & Intercept: & -0.03 & 0.232 & $>0.50$ \\
\hline & Density of non-feeding snails: & 0.00247 & 6.647 & $<0.01$ \\
\hline
\end{tabular}


The proportion of non-feeding snails aggregating was regressed on the above variables and also the density of non-feeding snails in the study area. The rationale for this last factor is that an individual with an inclination to aggregate will be more likely to find a clumping partner at greater densities. Of these variables, only the density of non-feeding whelks had any significant effect on the proportion of these non-feeding snails that were aggregating (Fig. 7).

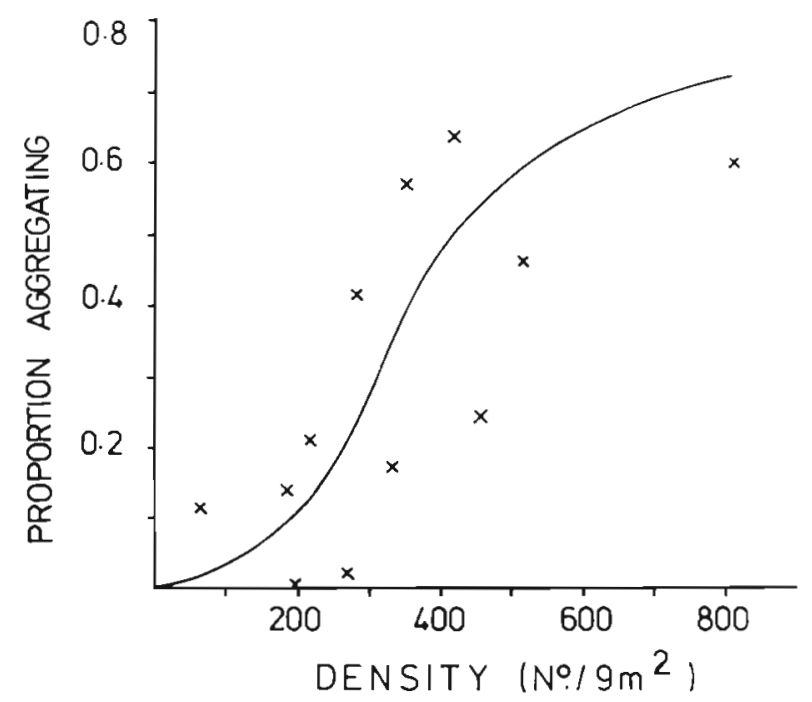

Fig. 7. Morula marginalba. Relation between proportion of a population aggregating and density of non-feeding snails

\section{DISCUSSION}

\section{Factors affecting horizontal distribution}

Examination of many shores in the Sydney region shows that Morula marginalba occurs on most rocky shores in the lower reaches of estuaries and on the open coast except for the most wave-battered headlands (Fig. 1). Within this range, shores made up of massed boulders frequently lack the snail. Experiments on a shore which spans the distributional limit associated with heavy waves (Fig. 3) indicate that simple physical dislodgement by waves is a sufficient explanation for the absence of the snails from areas of strong wave action. This is similar to the finding of Kitching et al. (1966) for the thick-shelled form of Thais lapillus.

In the same place where many Morula marginalba were swept from the shore by waves, 45 snails protected by cages in an $8 \mathrm{~d}$ experiment survived with no mortality and fed on barnacles: the rate of feeding, however, was reduced compared with whelks caged on more sheltered parts of the shore. Menge (1978b) sought an effect of wave exposure on feeding rates of
Thais lapillus and, although he found no significant effect, he thought that if he had done the experiment in spring or autumn, when storms are more frequent than in summer, strong wave action would have reduced the rate of feeding of $T$. lapillus. Unlike $M$. marginalba in the present experiments, many of Menge's $T$. lapillus died in his cages and some of the deaths were attributed to wave shock. The present study is, I believe, the first actual demonstration of an effect of waves on rate of feeding by whelks.

In seeking reasons for the absence of Morula marginalba from boulder-strewn shores, I observed Ozius truncatus moving about several such shores during nighttime low tide periods. While crabs have been named as major predators of some other muricid species, e.g. Shaskyus festivus and Ocenebra poulsoni (Fotheringham 1971) and Thais lapillus (Feare 1970a), the evidence offered has been the proportion of empty shells on the shore which have damage similar to that caused by crabs, together with the observations that crabs which co-occur with the whelks are able to prey upon them in the laboratory. In the habitats studied here for $M$. marginalba, dead shells are swept away by the sea and therefore are not available for such analysis. Laboratory trials have shown that the crab $O$. truncatus is capable of preying on $M$. marginalba and that some unsuccessful attacks leave the snail shells with a chipped lip. In a $M$. marginalba population close to an area with many $O$. truncatus, $15 \%$ of the population had chipped shells, medium-sized whelks having a greater proportion of damaged shells than large or small ones. Laboratory trials supported the hypothesis that susceptibility to predation by $O$. truncatus is inversely related to snail size.

Fotheringham (1971) stated that less than $1 \%$ of Shaskyus festivus and less than $2.5 \%$ of Ocenebra poulsoni in the populations he studied are destroyed annually by crabs. Feare (1970a) estimated the annual mortality of second and third year Thais lapillus at $52 \%$ and $36 \%$. Over $90 \%$ of this mortality appears to be attributable to predation by crabs. Kitching et al. (1966) found that predation by crabs totally excluded the thin-shelled form $T$. lapillus from some areas. On the available evidence I offer the hypothesis that, depending on the abundance of Ozius truncatus, its effects on Morula marginalba populations will range from slight and size-dependent mortality, through to total exclusion.

\section{Snail aggregations}

In the study of the snail's behaviour it was apparent that, unlike the Thais lapillus population described by Feare (1970b), feeding did not occur in aggregations. Most aggregations occurred in pools or crevices, where 
the prey of Morula marginalba were scarce. The proportion of the snail population feeding was not affected by reproductive activity or time of year, but increased in response to strong wave action or long tidal submersion in the period prior to sampling. The proportion of the population aggregating was inversely related to the proportion feeding. The proportion of the nonfeeding snails which were aggregating was not related to reproductive activity or time of year, and most copulating $M$. marginalba were not in aggregations. The proportion of non-feeding snails aggregating was positively related to the density of non-feeding snails.

I suggest that feeding and sheltering are alternative activities; Morula marginalba shelter in pools or crevices when the environment is unsuitable for feeding. At low densities, the probability of a sheltering snail finding another with which to clump would be expected initially to increase approximately as the square of density, then to level off at densities so great that all snails can find clumping partners. As can be seen in Fig. 7, the data are fitted quite well by a sigmoid curve, although they are insufficient to test the exact form of the relationship.

That strong waves favour feeding, rather than sheltering behaviour, is in apparent contrast to the result of the experiment which showed an adverse effect of strong waves on rate of feeding. The explanation may be that, within the snail's range of tolerance to wave exposure, the increased duration of submersion due to waves surging up the shore is the dominant effect. Certainly, when the heaviest waves seen in the period of this study were washing almost continuously over the shore, more Morula marginalba, and also Thais orbita, were out feeding on the Tamarama $B$ platform than I ever saw at any other time. These species apparently lack a behavioural response such as that shown by $T$. lapillus (Feare 1970b, Menge 1978a), T. canaliculata (Butler 1979) or Acanthina punctulata (Menge 1974) that makes them seek shelter in crevices, amongst attached organisms or in aggregations from the effects of heavy waves. Long submersion appears to favour feeding, long emersion to favour sheltering in pools and crevices, by M. marginalba at Tamarama.

\section{Factors effecting vertical distribution and dispersion}

On the shores discussed here and on many others, prey - including highly preferred species - are abundant higher on the shore than Morula marginalba occur. On the Tamarama B shore, in a study of the dispersion of different sizes of $M$. marginalba, from which areas of the platform above the snail's observed distribution were specifically excluded, correlations were found between densities of snail size groups and the cover of various sessile organisms. The progression, with increasing size of the snail - from Corallina $\mathrm{sp}$. to Galeolaria caespitosa to Tesseropora rosea dominated habitats represent a movement, with increasing age, from a moist habitat with very small prey, through an intermediate one, to a well-drained, higher intertidal habitat with large prey. The apparently different results on Shore B from that on Shore A, where there was no correlation of densities of the snail and prey, may be due in part to splitting the snails into 4 size categories, and partly to the exclusion of the higher levels of Shore B where adult $T$. rosea occurred without $M$. marginalba.

The situation of Tesseropora rosea is reminiscent of that described by Connell (1970) for Balanus glandula and Thais spp., in which the Thais eat the juvenile Balanus from the low shore, moving upshore as the barnacles are eliminated from the lower parts. The Thais begin to forage at the bottom again when the following year's juveniles grow large enough to be attractive, leaving in some areas a band of adult Balanus uneaten on the high shore. With Morula marginalba, no such regular, annual pattern of movement is apparent; and sequences of events vary in time and space. On the southern part of the Tamarama B shore in 1976, Morula feeding on T. rosea moved to progressively higher levels as the barnacles were eliminated lower down. This continued until no barnacles remained. Recruitment of $T$, rosea there in 1976 was effectively zero and all $M$. marginalba in this area remained low on the shore, in the Galeolaria zone until they moved upshore once again to feed on the dense $T$. rosea settlement of 1978 . On the less wave-exposed northern and central parts of the same shore, $M$. marginalba never succeeded in eliminating $T$. rosea from the upper shore in this period and the whelks persisted in the lower part of the zone of adult $T$. rosea with no downshore movement. At Cape Banks (Fig. 1) in 1977. a tagged population of $M$. marginalba was living amongst adult $T$. rosea. When the extremely dense 1978 settlement of $T$. rosea on the low shore reached approximately 6 mo of age, $90 \%$ of the tagged snails moved downshore and fed on the abundant juvenile barnacles. The young barnacles were eliminated from the lower shore within the next 6 mo and the snails returned to the adult barnacles on the upper shore (Moran 1980).

Morula marginalba do, therefore, only under some circumstances move downshore to feed on juvenile barnacles, then return to the higher level when these are eaten up. One of the factors which probably determines whether or not this happens is the number of Tesseropora rosea juveniles which survive to a size at which they attract adult snails. The settlement of $T$. 
rosea is very variable from year to year and the annual vertical movement reported by Connell (1970) for Thais in response to very regular annual settlement of Balanus glandula is not seen in Morula marginalba populations

The upper limit to foraging by intertidal predators is usually suggested to be determined by desiccation, e.g. Connell (1961a) for Thais lapillus and Dayton (1971) for the starfish Pisaster ochraceous. The hypothesis offered by Connell (1970) for the upper limit to predation by Thais emarginata, i.e. sufficient time in a single period of submersion to find and eat a barnacle, is not applicable to Morula marginalba, which continue to drill and eat a barnacle over several tidal cycles. Although the ultimate limits to the foraging range of predators are of great importance to the ecology of their prey, especially when mortality due to predation is almost total, as for very highly preferred prey, the dispersion of the predators within their potential limits is of equal importance as local density of predators will be a factor in variations of prey mortality from place to place. For intertidal predators, it appears that dispersion is a compromise between responses to physical factors and availability of prey.

The smallest Morula marginalba remain on the low shore despite the presence, sometimes, of suitable prey at higher levels. The largest snails are concentrated at the lowest level that their preferred prey are in sufficient abundance. If one assumes that small $M$. marginalba have different desiccation tolerance and prey size requirements from large ones then the main features of the model proposed by Butler (1979) for behaviour of Thais spp. with respect to shore-level size gradients could also explain the observed distribution and dispersion patterns of Morula, i.e. a whelk will move upwards when underwater until it encounters suitable food. When it encounters even mild physical stress it will move downwards. It will move downwards very readily in the absence of food, but if it finds food it may endure moderate stress during the time of exposure. The sensitivity of snails to heat stress or dehydration may vary with size. As Butler (1979) stated, his model is similar to that proposed by Underwood (1972a, b) for herbivourous intertidal gastropods.

\section{CONCLUSION}

As many students of the ecology of intertidal gastropods have found (see review by Underwood, 1979), to demonstrate which factors limit the distribution of these animals is not simple. Unlike the attached intertidal organisms, they are capable of changing their distribution in response to temporal variations in the degree of environmental stress encountered, be this on a twice daily, annual or some intermediate timescale. Similarly, they can respond by movement to changes in the distribution of their food. A complex model of several interacting factors seems to be required; predictions from this model could then be made and tested. While this has not been done for Morula marginalba in the present paper, a number of factors, wave shock, predation by crabs, availability of suitable prey and duration of emersion, have been identified as important and worthy of more detailed investigation.

Acknowledgements. I thank the many friends who generously gave their time to help with fieldwork; Dr. A. J. Underwood for encouragement, advice and inspiration; colleagues at the Ross St. Marine Lab. for stimulating discussions; P. Fairweather and J. Moran for constructive criticism of the manuscript. This work was supported by a Commonwealth Postgraduate Award and Universitiy of Sydney Research Grant.

\section{LITERATURE CITED}

Anderson, D. T. (1965). Further observations on the life histories of littoral gastropods in New South Wales. Proc. Linn. Soc. N. S. W. 90: 243-251

Bertness, M. D. (1977). Behavioural and ecological aspects of shore-level size gradients in Thais lamellosa and Thais emarginata. Ecology 58: 86-97

Black, R. (1978). Tactics of whelks preying on limpets. Mar. Biol. 46: 157-162

Butler, A. J. (1979). Relationships between height on the shore and size distributions of Thais spp. (Gastropoda: Muricidae). J. exp. mar. Biol. Ecol. 41: 163-194

Carriker, M. R. (1955). Critical review of biology and control of oyster drills Urosalpinx and Eupleura. Spec. scient. Rep. U. S. Fish Wildl. Serv. Fish 148: 1-150

Colman, J. (1933). The nature of the intertidal zonation of plants and animals. J. mar. biol. Ass. U. K. 18: 435-476

Connell, J. H. (1961 a). Effects of competition, predation by Thais lapillus, amd other factors on natural populations of the barbacle Balanus balanoides. Ecol. Monogr. 31: 61-104

Connell, J. H. (1961 b). The influence of competition and other factors on the distribution of the barnacle Chthamalus stellatus. Ecology 42: 710-723

Connell, J. H. (1970). A predator-prey system in the marine intertidal region. I. Balanus glandula and several predatory species of Thais. Ecol. Monogr. 40: 49-78

Coombs, V. (1973). Desiccation and age as factors in the vertical distribution of the dog-whelk, Nucella lapillus. J. Zool. 171: 57-66

Dayton, P. K. (1971). Competition, disturbance and community organization: the provision and subsequent utilization of space in a rocky intertidal community. Ecol. Monogr. 41: 351-389

Endean, R., Kenny, R., Stephenson, W. (1956). The ecology and distribution of intertidal organisms on the rocky shores of the Queensland mainland. Aust. J. mar. Freshwat. Res. 7 : 88-146

Evans, R. G. (1947). The intertidal ecology of selected localities in the Plymouth area. J. mar, biol. Ass. U. K. 37 : $173-218$

Fairweather, P. G., Underwood, A. J. (1983). The apparent diet of predators and biases due to different handling times of their prey. Oecologia (Berl.) 56: 169-179 
Feare, C. J. (1970a). Aspects of the ecology of an exposed shore population of dog whelks Nucella lapillus (L.) Oecologia (Berl.) 7: 117-126

Feare, C. J. (1970b). The adaptive significance of aggregation behaviour in the dog whelk Nucella lapillus (L.) Oecologia (Berl.) 20: 19-32

Fotheringham, N. (1971). Life history patterns of the littoral gastropods Shaskyus festivus (Hinds) and Ocenebra poulsoni Carpenter (Prosobranchia: Muricidae). Ecology 52: $742-757$

Jones, W. E., Demetropoulos, A. (1968). Exposure to waveaction: measurements of an important ecological parameter on rocky shores on Anglesey. J. exp. mar. Biol. Ecol. 2: $46-63$

Kitching, J. A., Muntz, L., Ebling, F. J. (1966). The ecology of Lough Ine: XV. The ecological significance of shell and body forms in Nucella. J. Anim. Ecol. 35: 113-126

Kohn, A. J., Leviten. P. J. (1976). Effect of habitat complexity on population density and species richness in tropical intertidal predatory gastropod assemblages. Oecologia (Berl.) 25: 199-210

Lewis, J. R. (1964). The ecology of rocky shores. English Universities Press, London

Menge, B. A. (1976). Organization of the New England rocky intertidal community: role of predation, competition, and environmental heterogeneity. Ecol. Monogr. 46: 355-393

Menge, B. A. (1978a). Predation intensity in a rocky intertidal community. Relation between predator foraging activity and environmental harshness. Oecologia (Berl.) 34: 1-16

Menge, B. A. (1978b). Predation intensity in a rocky intertidal community: effect of an algal canopy, wave-action, and desiccation on predator feeding rates. Oecologia (Berl.) 34: $17-35$

Menge, J. Lubchenco (1974). Prey selection and foraging period of the predaceous rocky intertidal snail, Acanthina punctulata. Oecologia (Berl.) 17: 293-316

Meyer, G. R., O'Gower, A. K. (1963). The ecology of six species of littoral gastropods. I. Associations between species and associations with wave action. Aust. J. mar. Freshwat. Res. 14: 176-193

Moran, M. J. (1980). The ecology, and effects on prey, of the predatory intertidal gastropod. Morula marginalba. Ph. D. thesis, University of Sydney

Morgan, P. R. (1972). The influence of prey availability on the distribution and predatory behavior of Nucella lapillus (L.). J. Anim. Ecol. 41:257-274

O'Gower, A. K., Meyer, G. R. (1971). The ecology of six species of littoral gastropods. III. Diurnal and seasonal variations in densities and patterns of distribution in three environments. Aust. J. mar. Freshwat. Res. 22: 35-40

Phillips, B. F. (1969). The population ecology of the whelk Dicathais aegrota in Western Australia. Aust. J. mar. Freshwat. Res. 20: 225-265

Spight, T. M. (1974). Sizes of populations of a marine snail. Ecology 55: 712-729

Stephenson, T. A., Stephenson, A. (1949). The universal features of zonation between tide marks on rocky coast. J. Ecol. 38: 289-305

Taylor, J. D. (1976). Habitats, abundance and diets of Muricacean gastropods at Aldabra Atoll. Zool. J. Linn. Soc. 59: 155-193

Taylor, J. D. (1978). Habitats and diet of predatory gastropods at Addu Attol, Maldives. J. exp. mar. Biol. Ecol. 31: 83-103

Underwood, A. J. (1972 a). Tide model analysis of the zonation of intertidal prosobranchs. I. Four species of Littorina (L.). J. exp. mar. Biol. Ecol. 9: 239-255

Underwood, A. J. (1972 b). Tide model analysis of the zonation of intertidal prosobranchs. II. Four species of trochids (Gastropoda, Prosobrachia). J. exp. mar. Biol. Ecol. 9; 257-277

Underwood, A. J. (1974). The reproductive cycles and geographical distribution of some common Eastern Australian prosobranchs (Mollusca: Gastropoda). Aust. J. mar. Freshwat. Res. 25: 63-88

Underwood, A. J. (1975). Intertidal zonation of prosobranch gastropods: analysis of densities of four coexisting species. J. exp. mar. Biol. Ecol. 19: 197-216

Underwood, A. J. (1979). The ecology of intertidal gastropods. Adv. mar. Biol. 16: 111-210

Underwood, A. J. (1981). Structure of a rocky intertidal community in New South Wales: patterns of vertical distribution and seasonal changes. J. exp. mar. Biol. Ecol. 51: $57-85$

Underwood, A. J., Denley, E. J., Moran, M. J. (1983). Experimental analyses of the structure and dynamics of midshore rocky intertidal communities in New South Wales. Oecologia (Berl.) 56: 202-219 